\title{
REFORÇAR LA QUALITAT IMPLICA REFORMULAR UN NOU PROFESSIONAL DE L'ENSENYAMENT
}

Els darrers mesos el sistema educatiu ha viscut canvis. Un ha afectat els mateixos professionals, amb una entrada substancial d'aquests a l'ensenyament públic deixant de banda condicions de treball precàries, d'interinitats. Ens n'alegrem. Sembla que aquest fet hauria d'ajudar a formar millors equips de treball $i$ a augmentar una qualitat que està en entredit. El canvi profund que ve, però, serà el que s'ha plasmat en el Pacte Nacional per l'Educació des de la Conselleria d'Ensenyament, signat per molts elements socials, però no pas per tots. La consellera ha remarcat que "totes les organitzacions implicades en el Pacte compartim un mateix objectiu: millorar la qualitat de l'educació" $i$ ha explicat que "el pacte educatiu suposa més estabilitat del sistema educatiu, més qualitat de l'educació, més innovació pedagògica i organitzativa i igualtat d'oportunitats per a tothom". La paraula "qualitat" hi surt reflectida repetidament. No és casual.

L'escola, però, passa per uns moments de disfuncionalitat, amb interrogants als quals sovint no hi ha hagut prou respostes per part dels agents involucrats: professors, pares i els mateixos alumnes. La interculturalitat sense bases sòlides sobre com encarar-la, les metodologies no gaire actives, la cultura de l'anar fent demanant el justet, el flux cultural sense uns referents de nació, l'alentiment en l'esforç per aprendre, l'actitud de saber els drets però no gaire els deures, la deixadesa del respecte per un treball basat en l'estudi... han estat, i són, condicionants que han influït, i influeixen, per aconseguir un ensenyament per formar ciutadans responsables.

Perquè, quins són els indicadors d'una qualitat a l'ensenyament? Prou n'hi ha com per afegir-n'hi un altre. Opinem que els alumnes, a l'acabar l'ensenyament obligatori, haurien de posseir unes estratègies bàsiques. Serien:

- Saber llegir. Llegir no és únicament articular sons, sinó confegir coneixement a allò que es llegeix. Sovint la lectura es dóna per aconseguida quan l'alumne només llegeix i no quan l'alumne entén. Si llegir és vehicular la comprensió d'un text, d'un gràfic, d'un diagrama, d'un anunci... amb la finalitat d'entendre el que diu i el que no diu, creiem que el temps de la lectura s'hauria d'ampliar. La lectura científica, pel que entenem, no és privativa de llengua. La pregunta seria: les diverses ciències fan el possible per aconseguir una lectura comprensiva?

- Saber escriure. Escriure no és únicament omplir un full amb més o menys encert, sinó confegir coneixement a allò que s'escriu. Sovint l'escriptura es dóna per aconseguida quan l'alumne només escriu, sense veure que escriure és quan l'alumne estructura un text, quan el fa entenedor. Pensem que s'aconsegueix quan l'alumne transmet una vivència intel-ligible, un sentit raonat a allò que vol donar a conèixer, amb un ordre lingüístic i conceptual. Malament es pot admetre un domini de l'escriptura quan l'ortografia, la sintaxi i el sentit vehiculats en un text tenen greus mancances. I difícilment aprendran els alumnes si no veuen rigor correctiu, per allò tan elemental que, sense un mínim d'exigència, sovint s'hi abraona la deixadesa.

- Saber comptar. Comptar no és únicament el domini de mecanismes més o menys automàtics per resoldre un problema o una qüestió. Sovint saber comptar es dóna per aconseguit quan l'alumne resol un exercici. Comptar no es té assumit fins que la interiorització del procediment és vist com un complement, i fins que la lògica de l'ordenació de l'espai de l'alumne se la faci seva i sigui capaç de resoldre l'exercici d'un problema d'un fet vivencial, amb sentit lògic. Si l'aprenentatge ha de ser coherent, fem servir prou les capacitats que ens dóna l'entorn per vertebrar una comprensió eficaç del saber comptar?

- Saber relacionar-se. Relacionar-se no és únicament la vivència d'un sentiment físic 0 intel-lectual amb altres persones, amb animals, amb objectes i amb artefactes. Saber relacionar-se és activar un comportament dòcil o transgressor amb elements vius $i$ inerts, en la recerca de l'espiritualitat. Així, els alumnes haurien d'assumir la complicitat de la relació amb l'entorn social, natural i cultural com a forma màxima de l'esperit educatiu. La pregunta és: arriben a entendre que els cal una relació racional i comprensiva amb les persones i amb tot el que els envolta, o només veuen les persones i les matèries com uns obstacles que fan nosa, sense implicació personal per entendre el procés?

Llegir, escriure, comptar i relacionar-se haurien de ser l'eix d'una escola inclusiva, entre altres més que podrien incorporar-s'hi, per formar ciutadans. Si els alumnes que surten de l'escola no posseeixen aquests sabers, la societat els classificarà de per vida. D'aquí el paper que es demana als professors, ja que en el present i futur de l'educació ens hi juguem molt. En aquest nou espai europeu caldrà aconseguir que els professors siguin persones amb un bon domini professional, amb excel.lent domini de les ciències referents, perquè la base per ensenyar és tenir ben estructurat el coneixement, amb una excel-lent capacitat didàctica per dissenyar i reconduir aprenentatges, perquè seria una farsa ensenyar allò que no se sap en una mena de pràctica teòrica, complementat amb una excel.lent base sociològicopsicològica per resoldre les variabilitats individuals en relació amb el grup. El domini dels tres camps, interrelacionats, hauria de propiciar un mestre i professor nou per a un alumne també nou. En aquestes hauríem-i haurem-d'estar. Segur. 